\title{
The Role of Insulin-Like Growth Factor 2 and Its Receptors in Human Tumors
}

\author{
Krešimir Pavelić, Damir Buković, and Jasminka Pavelić \\ Division of Molecular Medicine, Rudjer Bošković Institute, Zagreb, Croatia \\ Accepted September 30, 2002
}

\begin{abstract}
Insulin-like growth factor 2 (IGF-2) is important for normal development and growth of an organism. In humans it is encoded by 11 p 15.5 paternally expressed imprinted gene. It binds at least two different types of receptors: IGF type 1 (IGF-1R) and IGF-2/mannose 6-phospate receptors (IGF-2R/M6P). Ligand binding to IGF-1R provokes mitogenic and anti-apoptotic effects. IGF-2R/M6P has tumor
\end{abstract}

suppressor function; it mediates IGF-2 degradation. When the IGF-2 gene/protein is overexpressed, mostly as a consequence of loss of heterozygosity resulting in paternal allele duplication ( $\mathrm{LOH}$ ) or by loss of imprinting (LOI), it is involved in the development and progression of many tumors and overgrowth syndromes by autocrine or paracrine mechanisms.

\section{Introduction}

The insulin-like growth factors (IGFs) are mitogens that play a role in regulating cell proliferation, differentiation, and apoptosis. However, we, as well as other authors before us, also recognize the role of IGFs in neoplastic growth.

More than 20 years ago we described the involvement of IGFs in cancer (1-3). Increased glucose level in the blood of diabetic but normoinsulinemic mice was accompanied by suppressed growth of mammary carcinoma. The same tumors maintained in hypoinsulinemic mice grew faster after each subsequent transplantation into diabetic mice. The observed proliferation enhancement of mammary carcinoma was caused by de novo synthesis of insulin-like protein, by the tumor cells themselves (2). Affinity purified, tumor secreted insulin-like substance stimulated glucose uptake by rat epididymal adipose cells and competed with radiolabeled insulin for binding to these cells. Later we showed that IGFs appear in many experimental and human tumors (4-15) (Table 1). Increase in tumor size was paralleled by an elevation of IGFs in the serum of both diabetic and nondiabetic animals; this increase correlated with a decreased concentration of circulating glucose and an elevated concentration of growth hormone $(16,17)$. It appeared that IGF-1, as well as IGF-2 (13), could mediate autocrine stimulation of some murine (18) and human tumors (12).

Our early thinking was influenced by classical work on growth factor (particularly insulin)/tumor interaction, although we did not realize at that

Address correspondence and reprint requests to: Krešimir Pavelić, Rudjer Bošković Institute, Division of Molecular Medicine, Bijenička c. 54, P.O. Box 180, HR-10002 Zagreb, Croatia. Phone: +385-1-4680094; fax: +385-1-4561010; e-mail: pavelic@rudjer.irb.hr. time that there could be some distinct insulinoid entities important for tumor development and progression. Later, by use of a mathematical model based on experimental data we showed that some tumors induce their own growth by positive feedback (16). Today we know that IGF-2 is a major member of the IGF family in development of tumor hypoglycemia and tumor growth selfincitement.

The effects of IGFs are mediated through the IGF receptors, which are also involved in cell transformation induced by tumor virus proteins and oncogene products. Six binding proteins (IGF BPs) inhibit or enhance the action of IGFs; their effects on IGFs are regulated in part by IGF BP proteases. IGFs exert strong mitogenic and anti-apoptotic activity on various cancer cells; they also act synergistically with other growth factors and steroids, and antagonize the effect of antiproliferative molecules on cancer growth. Evidence suggests that certain lifestyles, such as one involving a high-energy diet, may increase IGF-1 levels, a finding that is supported by animal experiments indicating that IGFs may abolish the inhibitory effect of energy restriction on cancer growth (19).

\section{Insulin-Like Growth Factor 2}

IGF-2 is a regulatory peptide that appears to be involved in the progression of many tumors. The gene for human IGF-2 is found on the short arm of chromosome 11 (1 lp 15.5) and spans approximately $30 \mathrm{kbp}$ of chromosomal DNA (20-22). The gene consists of nine exons and the mature peptide (67 amino acids) is encoded by exons 7,8 , and 9. The IGF-2 gene is transcribed from four different promoters (P1-P4). P2-P4 are contained in CpG islands, and transcription from these promoters is subject to 
Table 1. Historical overview of ILA/IGFs expression in human neoplasms

\begin{tabular}{|c|c|c|c|}
\hline Type of Cancer & ILA*/IGF Types & Description & References \\
\hline $\begin{array}{l}\text { Hodgkin's lymphoma } \\
\text { non-Hodgkin lymphomas }\end{array}$ & ILA & $\begin{array}{l}\text { - Overexpression of insulin-like activity (ILA) } \\
\text { - Secretion by tumor cells proven in some cases }\end{array}$ & $3,7,8,9$ \\
\hline Renal carcinoma & insulin and glucagon & - Ectopic secretion by tumor cells & 4 \\
\hline $\begin{array}{l}\text { Cervical and endometrial } \\
\text { carcinomas }\end{array}$ & IGF-1, IGF-1R & $\begin{array}{l}\text { - ILA*; recently obtained IGF1 and IGF1R } \\
\text { overexpression }\end{array}$ & $\begin{array}{c}10 \\
\text { Unpublished }\end{array}$ \\
\hline $\begin{array}{l}\text { Bronchial and mammary } \\
\text { carcinomas }\end{array}$ & ILA & - ILA*; autocrine secretion & $\begin{array}{l}5 \\
6\end{array}$ \\
\hline Lung cancer & IGF-2, IGF-1R, IGF-2R & - IGF-2, IGF-1R, and IFG-2R overexpression & 11 \\
\hline Hemangiosarcoma & IGF-1 & - Autocrine growth stimulation & 12 \\
\hline Hemangiopericytomas & $\begin{array}{l}\text { IGF-1 } \\
\text { IGF-2 } \\
\text { IGF-1R }\end{array}$ & - Overexpression & $\begin{array}{l}13 \\
14 \\
15\end{array}$ \\
\hline Gastric cancer & $\begin{array}{l}\text { IGF-2 } \\
\text { IGF-1R }\end{array}$ & - Overexpression; autocrine secretion & Unpublished \\
\hline
\end{tabular}

*Insulin-like Activity Detected by Radioimmunoassay with insulin antibodies IGF-1, IGF-2, IGF-1R, and IGF-2R/M6P determined by RNAse protection assay, RT-PCR, or immunohistochemistry.

imprinting. Monoallelic expression from these promoters occurs mostly in fetal and young tissues. The Pl promoter, utilized primarily in adult liver tissue, is regulated differentially; it escapes imprinting and is expressed biallelically (23). Loss of imprinting (LOI) of promoters $\mathrm{P} 3$ and $\mathrm{P} 4$ have been implicated in Wilms' tumor (24) and rhabdomyosarcoma development (25). However, the usage of Pl promoter was also observed in tumors with IGF-2 gene LOI (26), suggesting that it could also be involved in the biallelic (due to the LOI) expression of IGF-2.

The IGF-2 gene can be expressed to produce proteins of various molecular weights. The most active form, with regard to binding of IGF receptors, is $7.5 \mathrm{kDa}$ (27). Larger forms lack posttranslational cleavage and have been implicated in hypoglycemia, which can accompany a variety of tumors. The secretion of IGF-2 by tumors and tumor-derived cell lines suggests that it may act as an autocrine regulator of cell proliferation.

IGF-2 is mitogenic for a number of cell types and can inhibit apoptosis. The frequent overexpression of this gene in human and animal tumors indicates that the IGF-2 may play an important role in tumor development. Transgenic mice that express the IGF-2 gene under the control of the H19 enhancer often develop multiple mammary tumors that have the ability to metastasize. Increased incidence of other solid tumors has also been noted in older mice. These findings indicate that IGF-2 expression increases the probability of malignant transformation, and that the mammary gland is at particularly high risk of tumor development in response to chronic increase in IGF-2 gene dosage (28).

\section{The Role of IGF Type 1 Receptor in Tumorigenesis}

IGF-2 binds at least two different types of receptors: IGF type 1 (IGF-1R) and IGF-2/mannose 6-phosphate (IGF-2/M6P) receptors (IGF-2R/M6P). IGF-1R has been identified as a potential control point for transformed cells (29) and is a well-defined target of IGF-2-modulated cell growth (30). The growth and tumorigenicity of transformed cells can be inhibited by the perturbation of IGF-1R function, and IGF-1R has been implicated in the protection of tumor cells from apoptosis. Autocrine or paracrine loops involving the IGF receptors and their ligand(s) may be crucial determinants for the in vivo growth and tumorigenicity of transformed epithelial cells.

IGF-1R is structurally similar to the insulin receptor. It is a heterotetrameric peptide consisting of two $\alpha$-subunits (Mr 135,000) and two transmembrane $\beta$-subunits ( $\mathrm{Mr} 90,000)$. Each $\beta$-subunit contains a tyrosine kinase domain, which activates the receptor by autophosphorylation. Despite functional and structural similarities, the receptors for IGF-1 and insulin are thought to play different biological roles during mammalian development and mature life. Whereas insulin plays a key role in regulation of a variety of metabolic processes, the IGFs appear to be more potent in promoting growth. Furthermore, insulin and $I G F-1$ receptors are the products of distinct genes, located on separate chromosomes that are controlled by different types of regulatory 
signals. The IGF- 1 receptor gene maps to $15 \mathrm{q} 25-26$, whereas the insulin receptor gene is localized on chromosome 19p band 13.3-p13.2 (31). Chromosomal assignment of IGF-1R to 15q25-26 coincides with the map position of the cellular protooncogene $c$-fes (32). Both of these receptors are tyrosine-specific protein kinases and their distinct roles in differentiation and cellular metabolism suggests that they utilize different pathways of signal transduction involving phosphorylation of different classes of substrates. Binding of IGF-1 to the extracellular portion of its cell surface receptor in some way initiates a cytoplasmic signal cascade that includes autophosphorylation of tyrosine residues within the intracellular portion of the insulin receptor $\beta$-subunit. Signal transduction through the plasma membrane may involve intermolecular signal transfer through the transmembrane domain or ligand-induced intermolecular receptor association. In the case of IGF-1 and insulin receptors, the heterotetrameric complex structure may represent a stabilized receptor dimer, in which a conformation change in one $\alpha-\beta$ subunit extracellular domain triggers the conversion of both $\beta$ cytoplasmic domains into an activated conformation (33).

The extensive homology of sequences downstream from the putative ATP-binding consensus sequence with members of the src family of tyrosine kinase proto-oncogenes, as well as the hormone receptors of this gene family, indicates that they represent the domain encoding the tyrosine kinase enzymatic activity. The nonapeptide Val-Leu-Ala-ProPro-Ser-Leu-Ser-Lys, which begins at residue 1073, is present at the exact position in the IGF-1 receptor where 70- and 100-residue heterologous insertion sequences are found in $c-f m s / C S F 1$ receptor and platelet-derived growth factor receptor structures $(34,35)$. The presence of such a highly heterologous sequence within otherwise highly conserved tyrosine kinase domains of gene family members appears highly significant and indicates a possible function of this subdomain in defining a specific receptor function.

The finding that the $v$-erbB and $v$-fms oncogenes of acute transforming retroviruses were derived from growth factor receptor proto-oncogenes by carboxyl-terminal sequence truncation further emphasizes the functional importance of this domain and raises the question as to whether the IGF-1 receptor gene represents a potential proto-oncogene. The transforming gene of the avian sarcoma virus UR-2 (v-ros) (36) shares sequence homology with tyrosine kinase family members and was found to be most similar to the insulin receptor (37).

In addition to being stimulated by IGF-2, IGF-1 receptors are overexpressed in some tumors. Overexpression of these receptors, independent of exogenous peptides, transforms cells to a phenotype of anchorage-independent growth (38). When activated by its ligands (IGF-1, IGF-2 or insulin at supraphysiologic concentrations), the IGF-1R transmits to its two major substrates, insulin receptor substrate 1 and Shc $(39,40)$, a signal that is subsequently transduced via the common signal-transducing pathway, through ras and raf, to the nucleus (41).

Recently, the importance of the IGF-1R in cell growth has been confirmed in vivo by the finding that mouse embryos with a targeted disruption by homologous recombination of the IGF-1R gene and the IGF-2 gene have a size at birth that is only $30 \%$ the size of wild-type littermates (42).

An intriguing finding is, however, the effect of the IGF-1R on transformation. Physiologic levels of IGF-1R are an obligatory requirement for the establishment and maintenance in the intact animal (43).

\section{IGF Type 2 Receptor/Mannose 6-Phosphate}

The IGF-2R/M6P or type 2 of IGF receptor is structurally and functionally different from the IGF-1R. The receptor is a $250-\mathrm{kDa}$ protein with a large extracellular domain, which binds M6P, lysosomal enzymes, and IGF-2. This suggests that IGF-2R/M6P may be involved in the clearance of IGF-2 from the circulation, in the modulation of trafficking of lysosomal enzymes such as cathepsin $\mathrm{D}$, as a protease present in some cancer tissues and possibly involved in matrix degradation or in signal transduction. The extracellular region of IGF-2R/M6P is composed of 15 homologous repeat units with an average length of 147 amino acids (44). Whereas repeats 1-3 and 7-9 each contain one M6P binding determinant involved in the binding of M6Pcontaining ligands (lysosomal enzymes, latent transforming growth factor- $\beta$ [TGF- $\beta$ ], proliferin, and LIF) $(45,46)$ the binding site of IGF-2 has been localized on repeat 11 (47). More recently, it has been reported that retinoic acid and urokinase-type plasminogen activator receptor bind to IGF-2R/M6P at a site or sites different from those involved in M6P or IGF-2 binding $(48,49)$.

Disruption of IGF-2R/M6P function has been implicated as a mechanism of increasing cell proliferation. Several missense IGF-2R/M6P mutations have been identified in human cancers. To determine what effects these mutations have on IGF-2R/M6P function Byrd et al. (50) constructed mutant and wild-type FLAG epitope-tagged IGF-2R/M6P constructs lacking the transmembrane and cytoplasmic domains and characterized these receptors for binding of IGF-2 and a M6P-bearing pseudoglycoprotein pentamannose (PMB) phosphate-bovine serum albumin. The Ile1572- $>$ Thr mutation eliminated IGF-2 binding but did not affect PMB. The Gly-1449-> Val and Cys$1262->$ Ser mutations each showed a $30-60 \%$ decrease in the number of sites available for binding to both ligands. In addition, the Gln-1445- $>$ His mutant underwent a time-dependent loss of IGF-2 binding, but not of PMB, that was not observed for the wild type. 
Although the binding sites for lysosomal enzymes and IGF-2 are distinct, reciprocal inhibition of binding between IGF-2 and lysosomal enzymes has been observed (27). IGF-2 has been shown to inhibit the cellular uptake of lysosomal enzymes and, in the case of $\beta$-galactosidase, inhibition of binding to purified receptor by IGF-2 was demonstrated (51). Although most of the IGF-2R/M6P is found intracellularly, where it functions to direct newly synthesized lysosomal enzymes to lysosomes, some receptors cycle to and from the plasma membrane where extracellular lysosomal enzymes and IGF-2 bind to the receptor and are internalized. DeLeon et al. (51) speculate that in a cell that is synthesizing IGF-2, the IGF-2 could act intracellularly to block the binding of lysosomal enzymes to the IGF-2R/M6P and thereby increase secretion of lysosomal enzymes and decrease the flux of lysosomal enzymes to lysosomes.

Mutant mice lacking IGF-2R/M6P usually die perinatally but are completely rescued from lethality in the absence of IGF-2. IGF-2R/M6P-deficient mice have elevated levels of circulating IGF binding protein (IGF BP-3) and show a strong IGF BP-6 immunoreactivity in all pancreatic islet cells and in secretory granules of different size in acinar cells and interlobular connective tissue of exocrine pancreas. Fibroblasts derived from homozygous null pups are unable to properly sort the lysosomal protease cathepsin $\mathrm{D}$, but are able to degrade endocytozed IGF BP-3 intracellularly, however, with lower efficiency (52).

At the cell surface, the IGF-2R/M6P is constitutively endocytosed, where its main role is thought to be the binding and internalization of the nonglycosylated polypeptide hormone IGF-2, with the minor role being the reuptake of secreted acid hydrolases (53). Motyka et al. (54) presented evidence that IGF2R/M6P is a death receptor for granzyme $\mathrm{B}$ during cytotoxic T-cell-induced apoptosis. The serine proteinase granzyme $B$ is crucial for the rapid induction of target cell apoptosis by T cells. Granzyme B was recently demonstrated to enter cells in a perforinindependent manner, thus predicting the existence of a cell surface receptor(s). Other nonacid hydrolase proteins besides IGF-2 that bind the cell surface IGF-2R/M6P include the precursor form of TGF- $\alpha$, leukemia inhibitory factor (55), and the herpes simplex virus (56).

Numerous reports show that IGF-2R/M6P is a tumor suppressor. Loss of heterozygosity has been reported in a variety of human malignancies including hepatocarcinoma, and adrenocortical tumors $(57,58)$, and aggressive early breast cancer $(59,60)$. Furthermore, the IGF-2R/M6P locus at $6 \mathrm{q}$ has been reported to be a hot spot for mutation in tumors including malignant melanoma (61), ovarian cancer (62), non-Hodgkin lymphoma (63), and renal cell carcinoma (64). This has usually been interpreted on the basis of the IGF-2R/M6P regulating responses of cells to IGF-2 signaling through the IGF-1R. However, Motyka's data suggest that tumors carrying mutated nonfunctional IGF-2R/M6P would also have an inherent resistance to the immune system, and this could play a critical role in the early escape of tumors and/or metastatic variants from host defenses. In addition, in Wilms' tumor and rhabdomyosarcomas, IGF-2 is overexpressed and is believed to interfere with signaling through IGF-1R and the routing of lysosomal proteins (51). An intriguing possibility is the recent observation that breast cancer lines and primary metastatic breast cancer cells secrete IGF-2R/M6P (65). The secreted material could act as a sink for granzyme B and thus prevent it from acting on the cell surface receptor. This would create a local immunosuppressive environment in a fashion analogous to secreted tumor necrosis factor receptor or Fas ligand (54). Downregulation of the IGF-2R/M6P promotes the growth of transformed cells by sustaining IGF-2, which binds to and activates IGF-1R and insulin receptor to increase intracellular growth signals (66).

The soluble form of IGF-2R/M6P could be released by cells in culture and circulate in the serum. It retains its ability to bind IGF-2 and blocks IGF-2-stimulated DNA synthesis in isolated rat hepatocytes. Scott and Weiss (67) showed that soluble receptor, at physiologic concentrations, can block proliferation of cells by IGF-2 and could therefore play a role in blocking tumor growth mediated by IGF-2.

\section{IGF-Binding Proteins and Proteases}

Several additional proteins regulate the function of both IGF-1 and IGF-2. These include at least six binding proteins (IGF BPI-6). The binding proteins, which are expressed coordinately in high tissue-specific and developmentally specific fashion, regulate IGF function in several ways, including transporting IGF-1 and IGF-2 in the circulation, delivering the IGFs to their target cells and modulating the interaction of IGFs with their receptors (68).

Decreased IGF-2 activity is accomplished by direct binding of IGF to the binding protein complex. Also, IGF feedback increases the synthesis of some binding proteins, further changing their levels. Increased IGF-2 activity follows cleavage of IGF binding proteins by specific proteases (69), some of which are dependent on IGFs for their enzymatic activity. IGF BP have a diverse repertoire of activity and play many roles in regulating the effects of IGF-2 upon tumor cells.

IGF action can be modulated by IGF binding proteases; they fall into three major categories. Kallikrein-like serine proteases, which cleave IGF BP-3, include PSA, gamma nerve growth factor (70), and plasmin (71). Thrombin, another serine protease, cleaves IGF BP-5 at physiologically relevant 
concentrations (within one order of magnitude of fibrinogen) (72). The second major category, cathepsins, are intracellular proteinases activated under acid conditions and may therefore play a role in certain physiologic and pathologic processes such as neoplastic infiltration (73). Matrix metalloproteinases comprise a family of peptide hydrolases that function in tissue remodeling by degrading extracellular matrix components such as collagen and proteoglycans (74). Proteolytic activity may play a role in normal and abnormal tissue proliferation by cleaving IGF BP into fragments with lower affinity for IGFs; these fragments allow increased levels of free IGFs to activate IGF-1R. The change in proportion of IGFs to IGF BPs could affect IGF BP protease activity, which in turn would modulate IGF/IGF BP/IGF-1R interactions.

\section{IGF-2-Induced Overgrowth and Mechanisms of Overexpression}

IGF-2 plays a fundamental role in human fetal growth displaying both tissue-specific and developmental regulation. The IGF-2 gene activity is regulated by genomic imprinting. The paternally inherited allele is expressed whereas the maternally inherited allele is silent as a consequence of methylation (75). As IGF-2 promotes mitogenesis and inhibits apoptosis, the growth disorders that involve excessive growth, as well as malignant tumor cells accumulation could be attributable to overexpression of IGF-2. Because genomic imprinting silences one copy of the IGF-2 gene, several different molecular errors can account for increased IGF-2 gene activity. In general, overgrowth occurs as the consequence of mutations that increase the availability of IGF-2 in the tissues or that increase the number of active IGF-2 genes. Molecular events that reactivate the silent maternal allele (LOI) or duplication of the functional paternal allele (loss of heterozygosity $[\mathrm{LOH}])$ can thus give rise to an overgrowth phenotype. In addition to these two events, increased activity of the IGF- 2 gene can be also accomplished by excessive transcriptional activation, loss of transcriptional suppression, or alteration in IGF BPs (Table 2) (76).

LOI is the molecular abnormality observed first in Wilms' tumor, and later on in a variety of other embryonal and adult tissue tumors (77-82). In Wilms' tumor it involves competition between IGF2/H19 imprinting cluster for the use of the enhancers. This includes activation of the normally silent maternal IGF-2 allele, and silencing of the normally active maternal allele of $\mathrm{H} 19$ gene, by methylation of a differentially methylated region (DMR) (83) (also called imprinting control center, ICR) (84) upstream of the maternal copy of the HI9 gene $(80,82)$. As a consequence, there is abrogation of binding of the CTCF transcription factor to DMR (a core of five CpG islands), which acts as an
Table 2. Mechanisms of increased IGF-2 gene/protein activities

Normally IGF-2 is expressed from the paternal allele with the Maternal allele being transcriptionally silent (imprinting) (75).

Loss or imprinting (LOI)

Maternal allele becomes re-imprinted; transcription occurs from two IGF-2 alleles (23-26,77-91).

Loss of heterozygosity $(\mathrm{LOH})$

$\mathrm{LOH}$ is associated with duplication of the active paternal IGF-2 allele; transcription occurs from two IGF-2 alleles leading to higher mRNA level (93-98).

Altered binding proteins Cleavage of IGF BPs by binding protein-specific proteases increase IGF-2 activity $(69,100-102)$.

Loss of transcriptional suppressor protein Suppressor proteins (WT-1, p53, and possibly CTCF), which bind to sequences in the IGF-2 enhancer/ promoter regions, prevent transcription of IGF-2; when absent or mutated IGF-2 gene transcription increases (104-108).

Activation of transcription factors Those that positively regulate IGF-2 (104-108).

Altered IGF-2 receptor/mannose-6-phosphate Mutation in IGF-2 binding site required for the degradation of the IGF-2 decreases IGF-2 bioavailability (57-64).

For details see reference 76 .

insulator that prevents binding of enhancers to promoter regions in the IGF-2 gene. Thus, enhancer regions distal to $\mathrm{H} 19$ gene would have free access to the IGF-2 gene promoter leading to IGF-2 activation $(85,86)$. However, because some Wilms' tumors with normal imprinting of IGF-2 gene also show increased methylation of DMR regions, it seems that methylation is necessary but not sufficient for LOI in Wilms' tumor (83). Although there is no doubt that inactivation of $\mathrm{H} 19$, by methylation of $5^{\prime}$ enhancer region, leads to relaxation of IGF-2 imprinting in Wilms' tumor, other methylation-sensitive elements (CpG islands) located around and in promoter (P2-P4) regions of IGF-2 are also included in LOI development in Wilms' tumor (24) and rhabdomyosarcoma (25). It seems however, that Pl promoter-specific expression might also be involved in the biallelic expression of IGF-2, as has been shown for human cervical and ovarian carcinomas $(26,87)$. Whether this is true for other human malignancies is still an open question. The occurrence of LOI, as well as LOH at $11 \mathrm{pl} 15$ resulting in paternal disomy, doubles the potential for IGF-2 gene transcription, due to two active gene copies, leading to higher mRNA level, as shown in different tumors and overgrowth syndromes (88-99). Altered IGF BP activity is another potential mechanism of increased 
IGF-2 activity (100-102). IGF-2 activity depends on individual IGF BP in that binding of IGF-2 to the binding proteins decreases its activity (103). Alternatively, increased IGF-2 activity follows cleavage of IGF BP by binding protein-specific protease (69). The activation of transcription factors, that positively regulate IGF-2, as well as loss of activity of transcriptional suppressor proteins (WT1, p53, and possibly CTCF) which bind to sequences in the IGF-2 enhancer/promoter or IGF$2 / \mathrm{H} 19$ enhancer region and prevent transcription of the IGF-2 gene, could also be a mechanism of elevated IGF-2 (104-108). Finally, any disruption in the IGF-2 receptor/M6P responsible for IGF-2 degradation will also increase IGF-2 bioavailability. Thus, we conclude that IGF-2-dependent cancers can occur due to both genetic and epigenetic events.

\section{Treatment of IGF-2-Dependent Tumors}

IGF-2, together with other members of peptides from insulin-like growth factor family of ligands (insulin, IGF-1), receptors (IGF-1R, IGF-2R/M6P), and IGF BP, form highly regulated network of interactions. Disruption of these interactions or perturbation in the level of any IGF can lead to cancer formation. Considering the role of IGF-2 overexpression in neoplastic growth, (Figure 1 and Table 3) a reasonable choice for the treatment of IGF-dependent cancers would be to reverse IGF-2 overexpression at the gene level or to prevent its action by increased degradation by IGF-2R/M6P and/or blocking by IGF BPs. However, there are only a limited numbers of papers that describe targeting of IGF-2 production as cancer therapy strategy. For instance, it was shown that an analog of gonadotropin-releasing hormone (GnRH), tryptorelin, exerts a biphasic growth effect on ovarian cancer cells (that express GnRH binding sites), by a mechanism of diminished autocrine production of IGF-2 (109). More precisely,

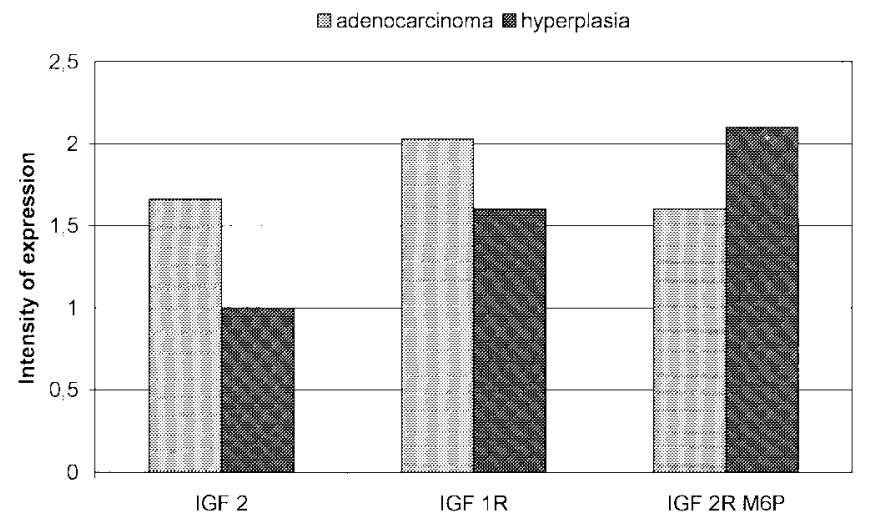

Fig. 1. Semiquantitative immunohistochemical detection of IGF-2, IGF-1R, IGF-2R M6P in 82 primary endometrial adenocarcinomas (stages I, II, and III) and 26 endometrial hyperplasias. Details are presented in Table 3. cellular proliferation was enhanced during the first $24 \mathrm{hr}$ of cell exposure to tryptorelin, but longer incubation resulted in growth inhibition. The mitogenic effect of tryptorelin was inhibited after neutralization of secreted IGF-2 with IGF BP or anti-IGF-2 antibody, while growth inhibition was accompanied by a complete lack of IGF-2 mRNA, indicating that cessation of autocrine production of IGF-2 participated in cancer growth inhibition. Similarly, the GnRH antagonist, SB-75, inhibited growth of ovarian (110), endometrial (111), and breast cancer cells (112), again by inhibition of IGF-2 secretion. The inhibitory effect on cell growth via down-regulation of IGF-2 production by certain agents was observed by Csernus et al. (113) as well. They suggested that antagonistic analogs of growth hormone releasing hormone (GHRH) could inhibit growth of certain tumors not only by binding the GRHR-GR-IGF-1 axis, but also by reducing IGF-2 production and by interfering with the autocrine regulatory pathway. Antagonists of GHRH directly block the expression of mRNA IGF-2 and, as a consequence, the production of IGF-2.

Blocking of IGF-1R seems to be a promising approach for the development of an IGF-2-dependent cancer therapy strategy. Receptor function can be abrogated by utilizing monoclonal antibodies against receptors such as $\alpha$ IR3 (114), use of the polyanionic compound suramine (115), utilizing phosphorylationdefective analogs of the IGF-1 ligand (114), or exploiting antisense oligodeoxynucleotides directed against the IGF-1R mRNA. The $\alpha$ IR3 monoclonal antibody recognizes human IGF-IR and neutralizes IGF-1 and IGF-2-mediated signal transduction pathway. Its blocking effect on IGF-1- and IGF2-mediated responses has been shown in vitro and in vivo $(11,38,116,117)$. This approach was also tested and supported with results of our previous experiments conducted on malignant hemangiopericytomas $(13,14)$. According to Arteaga (118) blockade of IGF-1R by aIR3 antibody is an effective therapeutic approach, especially when used in conjunction with other agents that also target the IGF system. The experiments based on antisense strategies against the IGF-1R (118-120) have also shown that a decrease in the number of IGF-1R causes reversal of the transformed phenotype $(121,122)$.

Potential candidates in the therapy of IGF-2dependent tumors are IGF BP that have been shown to neutralize the mitogenic effects of IGF-2. There have been several recent reports indicating that retinoids may affect growth of IGF-2-dependent breast and prostate tumor cells by increasing the production of IGF BP, especially IGF BP-3 (123-126). Alternatively, growth inhibition of breast cancer could be achieved by inhibition of IGF BP-3 protease activity by administration of megestrol acetate, which reduces delivery of IGFs to the tissue (127). 
Table 3. IGF-2 and IGF-1 receptor immunostaining in endometrial adenocarcinomas of the corpus uteri (stages II and III)

\begin{tabular}{lccccr} 
& \multicolumn{5}{c}{ Intensity of Staining } \\
\cline { 2 - 5 } $\begin{array}{l}\text { Type of } \\
\text { Analysis }\end{array}$ & 0 & 1 & 2 & 3 & Total \\
\hline IGF-2 & $12(17 \%)$ & $20(28 \%)$ & $16(22 \%)$ & $24(33 \%)$ & 72 \\
IGF-1R & $3(4 \%)$ & $12(17 \%)$ & $20(28 \%)$ & $37(51 \%)$ & 72
\end{tabular}

Seventy-two human primary endometrial adenocarcinomas (of stages II and III) were obtained from Croatia Human Tumor Bank. Enodmetrial carcinomas were pure or endometroid adenocarcinomas, composed entirely of glandular cells. Immunohistochemical tests were performed on formalin-fixed, paraffin-embedded tissue using the avidin-biotin-peroxidase method. Sections, cut at $4 \mu \mathrm{m}$, were subjected to a heat-induced epitope retrieval technique in $10 \mathrm{mM}$ citrate buffer (pH 6.0) in an $850 \mathrm{~W}$ microwave for $10 \mathrm{~min}$. AntiIGF-2, a mouse monoclonal antibody (Upstate Biotechnologies, Lake Placid, NY, USA), was diluted 1:50, and incubated for 15-18 hrs. Anti-IGF-1R (Santa Cruz Biotechnologies, Santa Cruz, CA, USA), were diluted 1:100 and also incubated for 15-18 hrs. Detection was achieved using the DAKO LSAB 2 kit, according to manufacturer's instructions. Negative controls were stained by substitution of the primary antibodies with non-immune mouse or rabbit immunoglobulins. Appropriate positive controls (thyroid gland tissue for IGF-1R, and Wilms' tumor for IGF-2) were stained positively. The tumor cells showed strong diffuse cytoplasmic immunopositivity for IGF-2 and cytoplasmic and focal membranous reactivity for IGF-1R. The intensity of staining was arbitrary judged as weak $(+)$, moderate $(++)$, or strong $(+++)$.

\section{Conclusion}

The IGF-2 and their receptors are critically important for normal growth and early development of the organism. However, IGF-2 is also implicated in numerous pathologic states, including malignancy, where it serves as an endocrine, autocrine, and paracrine stimulator of mitogenesis, survival, and cellular transformation. IGF-2 is commonly overexpressed in many tumors and may enhance tumor growth by binding to IGF-1R, a potential control point for transformed cells. In addition to being stimulated by IGF-2, IGF-1R may also be overexpressed in some tumors, leading to a phenotype of anchorage-independent growth. In contrast to IGF-1R, the IGF-2R/M6P mediates the clearance of IGF-2. When mutated, the level of circulating IGF-2 increases. Considering the role of IGF-2 in neoplastic control, modulation of IGF physiology seems to be a reasonable target for the treatment of IGF-2dependent tumors. Thus, targeting IGF-2 and/or its receptors by "antisense" or monoclonal antibody approach may provide an effective and practical cancer gene therapy.

\section{Acknowledgments}

This work was supported by grants 0098092 and 0098093 from the Ministry of Science and Technology, Republic of Croatia.

\section{References}

1. Pavelić K. (1979) Aplastic carcinoma in diabetic mice: hyperglycemia-suppressed proliferation rate and insulin synthesis by tumor cells. J. Natl. Cancer Inst. 62: 139-141.

2. Pavelić K, Ferle-Vidović A, Osmak M, et al. (1981) Synthesis of immunoreactive insulin in vitro by aplastic mammary carcinoma preconditioned in diabetic mice. J. Natl. Cancer Inst. 67: 687-688.
3. Pavelić K, Vuk-Pavlović S. (1983) C-peptide does not parallel increases of substances immunologically cross-reactive with insulin in non-Hodgkin lymphoma patients. Blood 61: 925-928.

4. Pavelić K, Popović M. (1981) Insulin and glucagon secretion by renal adenocarcinoma. Cancer (Philad.) 48: 98-100.

5. Pavelić LJ, Pavelić K, Vuk-Pavlović S. (1984) Human mammary and bronchial carcinomas. In vivo and in vitro secretion of substances immunologically cross-reactive with insulin. Cancer 53: 2467-2471.

6. Baltić V, Levanat S, Petek M, et al. (1985) Elevated levels of substances immunologically cross-reactive with insulin in blood of patients with malignant and nonmalignant pulmonary tissue proliferation. Oncology 42: 174-178.

7. Pavelić K, Pekić B, Slijepčević M, Popović M. (1980) Insulin levels in Hodgkin's disease. Br. J. Haematol. 46: 133-135.

8. Pavelić K, Odavić M, Pekić B, et al. (1982) Correlation of substance(s) immunologically cross-reactive with insulin, glucose and growth hormone in Hodgkin lymphoma patients. Cancer Lett. 17: 81-86.

9. Čabrijan T, Levanat S, Pekić B, et al. (1991) The role of insulin-related substance in Hodgkin's disease. J. Cancer Res. Clin. Oncol. 117: 615-619.

10. Pavelić K, Bolanča M, Veček N, et al. (1982) Carcinomas of the cervix and corpus uteri in humans: stage-dependent blood levels of substance(s) immunologically cross-reactive with insulin. J. Natl. Cancer Inst. 68: 891-894.

11. Pavelić J, Pavelić LJ, Karadža J, et al. (2002) Insulin-like growth factor family and combined antisense approach in therapy of lung carcinoma. Mol. Med. 8: 149-157.

12. Pavelić K, Vrbanec D, Marušić S, et al. (1986) Autocrine tumor growth regulation by somatomedin C: an in vitro model. J. Endocrinol. 109: 233-238.

13. Pavelić K, Spaventi Š, Glunčić V, et al. (1999) The expression and role of insulin-like growth factor II in malignant hemangiopericytomas. J. Mol. Med. 77: 865-869.

14. Pavelić K, Pavelić ZP, Čabrijan T, et al. (1999) Insulin-like growth factor family in malignant haemangiopericytomas: the expression and role of insulin-like growth factor I receptor. J. Pathol. 188: 69-75.

15. Pavelić K, Čabrijan T, Hraščan R, et al. (1998) Molecular pathology of hemangiopericytomas accompanied by severe hypoglycemia: oncogenes, tumor-suppressor genes and the 
insulin-like growth factor family. J. Cancer Res. Clin. Oncol. 124: 307-314.

16. Bajzer Ž, Pavelić K, Vuk-Pavlović S. (1984) Growth selfincitement in murine melanoma B-16: a phenomenological model. Science 225: 930-932.

17. Vuk-Pavlović Z, Pavelić K, Vuk-Pavlović S. (1986a) Modulation of in vitro growth of murine myeloid leukemia by an autologous substance immunochemically cross-reactive with insulin and antiinsulin serum. Blood 67: 1031-1035.

18. Vuk-Pavlović S, Opara EC, Levanat S, et al. (1986b) Autocrine tumor growth regulation and tumor-associated hypoglycemia in murine melanoma B16 in vivo. Cancer Res. 46: 2208-2213.

19. Yu H, Rohan T. (2000) Role of the insulin-like growth factor family in cancer development and progression. J. Natl. Cancer Inst. 92: 1472-1489.

20. Jansen M, van Schaik FM, Ricker A, et al. (1983) Sequence of cDNA encoding human insulin-like growth factor I precursor. Nature 306: 609-611.

21. Dull TJ, Gray A, Hayflick JS, et al. (1984) Insulin-like growth factor II precursor gene organization in relation to insulin gene family. Nature 310: 777-781.

22. Brissenden JE, Ullrich A, Francke U. (1984) Human chromosomal mapping of genes for insulin-like growth factors I and II and epidermal growth factor. Nature 310: 781-784.

23. Vu TH, Hoffman AR. (1994) Promoter-specific imprinting of the human insulin-like growth factor-II gene. Nature 371: 714-717.

24. Issa JPJ, Vertino PM, Boehm CD, et al. (1996) Switch from monoallelic to biallelic human IGF2 promoter methylation during aging and carcinogenesis. Proc. Natl. Acad. Sci. U.S.A. 93: 11757-11762.

25. Zhan S, Shapiro D, Zhan S, et al. (1995) Concordant loss of imprinting of the human insulin-like growth factor II gene. J. Biol. Chem. 270: 27983-27986.

26. Kim SJ, Park SE, Lee C, et al. (2002) Alterations in promoter usage and expression levels in insulin-like growth factor-II and $\mathrm{H} 19$ genes in cervical carcinoma exhibiting biallelic expression of IGF-II. Biochim. Biophys. Acta 1586: 307-315.

27. Kiess W, Yang Y, Kessler U, et al. (1994) Insulin-like growth factor II (IGF-II) and the IGF-II mannose-6-phosphate receptor-the myth continues. Hormone Res. 41: 66-73.

28. Pravtcheva DD, Wise TL. (1998) Metastasizing mammary carcinomas in $\mathrm{H} 19$ enhancers IGF2 transgenic mice. J. Exp. Zoology 281: 43-57.

29. Resnicoff M, Sell C, Rubini M, et al. (1994) Rat glioblastoma cells expressing an antisense RNA to the insulin-like growth factor-1 (IGF-1) receptor are nontumorigenic and induce regression of wild-type tumors. Cancer Res. 54: $2218-2222$.

30. Rubin R, Baserga R. (1995) Insulin-like growth factor-I receptor. Its role in cell proliferation, apoptosis, and tumorigenicity. Lab. Invest. 73: 311-331.

31. Yang-Feng Y, Ullrich A, Francke U. (1985) Gene for human insulin receptor: localization to site on chromosome 19 involved in pre-B-cell leukemia. Science 228: 728-731.

32. Harper ME, Franchini G, Love J, et al. (1983) Chromosomal sublocalization of human c-myb and c-fes cellular onc genes. Nature 304: 169-171.

33. Ullrich A, Gray A, Tam AW, et al. (1986) Insulin-like growth factor I receptor primary structure: comparison with insulin receptor suggests structural determinants that define functional specificity. ЕMBO J. 5: 2503-2512.

34. Coussens L, Yang-Feng TA, Liao Y-C, et al. (1985) Tyrosine kinase receptor with extensive homology to EGF receptor shares chromosomal location with neu oncogene. Science 230: 1132-1139.

35. Sherr CJ, Rettenmier CW, Sacca R, et al. (1985) The c-fms proto-oncogene products related to the receptor for the mononuclear phagocyte growth factor, CSF-1. Cell 41: 665-676.

36. Neckameyer WS, Wang LH. (1985) Nucleotide sequence of avian sarcoma virus UR2 and comparison of its transforming gene with other members of the tyrosine protein kinase oncogene family. J. Virol. 53: 879-884.

37. Ullrich A, Bell JR, Chen EY, et al. (1985) Human insulin receptor and its relationship to the tyrosine kinase family of oncogenes. Nature 313: 56-761.

38. Kaleko M, Rutter WG, Miller AD. (1990) Overexpression of the human insulin like growth factor 1 receptor promotes ligand-dependent neoplastic transformation. Mol. Cell. Biol. 10: 464-473.

39. White MF, Kahn CR. (1994) The insulin signaling system. J. Biol. Chem. 269: 1-4.

40. Myers MG Jr, Sun XJ, Cheatham B, et al. (1993) IRS-1 is a common element in insulin and insulin-like growth factor-1 signaling to the phosphatidylinositol 3'-kinase. Endocrinology 132: 1421-1430.

41. Crews CM, Erikson RL. (1993) Extracellular signals and reversible protein phosphorylation. What to Mek of it all. Cell 74: 215-217.

42. Liu JP, Baker J, Perkins AS, et al. (1993) Mice carrying null mutations of the genes encoding insulin-like growth factor I (Igf-I) and type 1 IGF receptor (Igflr). Cell 75: 59-72.

43. Baserga R. (1995) The insulin-like growth factor I receptor: a key to tumor growth? Cancer Res. 55: 249-252.

44. Kornfeld S. (1992) Structure and function of the mannose 6-phosphate/insulin like growth factor II receptors. Ann. Rev. Biochem. 61: 307-330.

45. Dahms NM, Rose PA, Molkentin JD, et al. (1993) The bovine mannose 6-phosphate/insulin-like growth factor II receptor. The role of arginine residues in mannose 6-phosphate binding. J. Biol. Chem. 268: 5457-5463.

46. Byrd JC, MacDonald RG. (2000) Mechanisms for high affinity mannose 6-phosphate ligand binding to the insulin-like growth factor II/mannose 6-phosphate receptor. Negative cooperactivity and receptor oligomerization. J. Biol. Chem. 275: 18638-18646.

47. Garmroudi F, MacDonald RG. (1994) Localization of the insulin-like growth factor II (IGF-II) binding/cross-linking site of the IGF-II/mannose 6-phosphate receptor to extracellular repeats 10-11. J. Biol. Chem. 269: 26944-26952.

48. Nykjaer A, Christensen EI, Vorum H, et al. (1998) Mannose 6-phosphate/insulin-like growth factor II receptor targets the urokinase receptor to lysosomes via a novel binding interaction. J. Cell. Biol. 141: 815-828.

49. Kang JX, Li Y, Leaf A. (1997) Mannose-6-phosphate/insulinlike growth factor-II receptor is a receptor for retinoic acid. Proc. Natl. Acad. Sci. U.S.A. 94: 13671-13676.

50. Byrd JC, Devi GR, DeSouza AT, et al. (1999) Disruption of ligand binding to the insulin-like growth factor II/mannose 6-phosphate receptor by cancer-associated missense mutations. J. Biol. Chem. 274: 24408-24416.

51. DeLeon DD, Terry C, Asmerom Y, et al. (1996) Insulin-like growth factor II modulates the routing of cathepsin D in MCF-7 breast cancer cells. Endocrinology 137: 185 1-1859.

52. Braulke T, Dittmer F, Gotz W, et al. (1999) Alteration in pancreatic immunoreactivity of insulin-like growth factor (IGF)binding protein (IGFBP)- 6 and in intracellular degradation of IGFBP-3 in fibroblasts of IGF-II receptor/IGF-II-deficient mice. Horm. Metab. Res. 31: 235-241.

53. Dahms NM. (1996) Insulin-like growth factor II/cationindependent mannose 6-phosphate receptor and lysosomal enzyme recognition. Biochem. Soc. Trans. 24: 136-141.

54. Motyka B, Korbutt G, Pinkoski MJ, et al. (2000) Mannose 6phosphate/insulin-like growth factor II receptor is a death receptor for granzyme $\mathrm{B}$ during cytotoxic T-cell-induced apoptosis. Cell 103: 491-500.

55. Blanchard F, Raher S, Duplomb L, et al. (1998) The mannose 6-phosphate/insulin-like growth factor II receptor is a nanomolar affinity receptor for glycosylated human leukemia inhibitory factor. J. Biol. Chem. 273: 20886-20893.

56. Brunetti CR, Burke RL, Kornfeld S, et al. (1994) Herpes simplex virus glycoprotein D acquires mannose B-phosphate residues and binds to mannose 6-phosphate receptors. J. Biol. Chem. 269: 17067-17074. 
57. Kishimoto Y, Morisawa T, Kitano M, et al. (2001) Loss of heterozygosity of the mannose 6-phosphate/insulin-like growth factor II receptor and p53 genes in human hepatocellular carcinoma. Hepatol. Res. 20: 68-83.

58. Leboulleux S, Gaston V, Boulle N, et al. C (2001) Loss of heterozygosity at the mannose 6-phosphate/insulin-like growth factor 2 receptor locus: a frequent but late event in adrenocortical tumorigenesis. Eur. J. Endocrinol. 144: 163-168.

59. Chappell SA, Walsh T, Walker RA, et al. (1997) Loss of heterozygosity at the mannose 6-phosphate insulin-like growth factor 2 receptor gene correlates with poor differentiation in early breast carcinomas. Br. J. Cancer 76: 1558-1561.

60. Rey JM, Theillet C, Brouillet JP, et al. (2000) Stable amino-acid sequence of the mannose-6-phosphate/insulinlike growth-factor-II receptor in ovarian carcinomas with loss of heterozygosity and in breast-cancer cell lines. Int. J. Cancer 85: 466-473.

61. Millikin D, Meese E, Vogelstein B, et al. (1991) Loss of heterozygosity for loci on the long arm of chromosome 6 in human malignant melanoma. Cancer Res. 51: 5449-5453.

62. Foulkes WD, Ragoussis J, Stamp GW, et al. (1993) Frequent loss of heterozygosity on chromosome 6 in human ovarian carcinoma. Br. J. Cancer 67: 551-559.

63. Gaidano G, Hauptschein RS, Parsa N, et al. (1992) Deletions involving two distinct regions of $6 \mathrm{q}$ in B-cell non-Hodgkin lymphoma. Blood 80: 1781-1787.

64. Morita R, Saito S, Ishikawa J, et al. (1991) Common regions of deletion on chromosomes $5 \mathrm{q}, 6 \mathrm{q}$, and $10 \mathrm{q}$ in renal cell carcinoma. Cancer Res. 51: 5817-5820.

65. Confort C, Rochefort H, Vignon F. (1995) Insulin-like growth factors (IGFs) stimulate the release of $\alpha 1$-antichymotrypsin and soluble IGF-II/mannose 6-phosphate receptor from MCF7 breast cancer cells. Endocrinology 136: 3759-3766.

66. Osipo C, Dorman S, Frankfater A. (2001) Loss of insulinlike growth factor II receptor expression promotes growth in cancer by increasing intracellular signaling from both IGF-I and insulin receptors. Exp. Cell Res. 264: 388-396.

67. Scott CD, Weiss J. (2000) Soluble insulin-like growth factor II/mannose 6-phosphate receptor inhibits DNA synthesis in insulin-like growth factor II sensitive cells. J. Cell. Physiol. 182: 62-68.

68. Werner H, Adamo M, Roberts CT Jr, et al. (1994) Molecular and cellular aspects of insulin-like growth factor action. Vitamins Hormones 48: 1-58.

69. Chernausek SD, Smith CE, Duffin KL, et al. (1995) Proteolytic cleavage of insulin-like growth factor binding protein (IGFBP-4). Localization of cleavage site to the nonhomologous region of the native IGFBP-4. J. Biol. Chem. 270: 11377-11382.

70. Rajah R, Bhala SE, Nunn SE, et al. (1996) 7S nerve growth factor is an insulin-like growth factor binding protein protease. Endocrinology 137: 2676-2682.

71. Booth BA, Boes M, Dake BL, et al. (1999) Isolation and characterization of plasmin-generated bioactive fragments of IGFBP-3. Am. J. Physiol. 39: E450-E454.

72. Zheng B, Clarke JB, Busby WH, et al. (1998) Insulin-like growth factor-binding protein- 5 is cleaved by physiological concentrations of thrombin. Endocrinology 139: 1708-1714.

73. Nunn SE, Peehl DM, Cohen P. (1997) Acid-activated insulin-like growth factor binding protein protease activity of cathepsin D in normal and malignant prostatic epithelial cells and seminal plasma. J. Cell. Physiol. 171: 196-204.

74. Grimberg A, Cohen P. (2000) Role of insulin-like growth factors and their binding proteins in growth control and carcinogenesis. J. Cell. Physiol. 183: 1-9.

75. Morison IM, Reeve AE. (1998) Insulin-like growth factor 2 and overgrowth: molecular biology and clinical implications. Mol. Med. Today 4: 110-115.

76. Toretsky JA, Helman LJ. (1996) Involvement of IGF-II in human cancer. J. Endocrinol. 149: 367-372.

77. Ogawa O, Eccles MR, Szeto J, et al. (1993) Relaxation of insulin-like growth factor II gene imprinting in Wilms tumour. Nature 362: 749-751.
78. Rainier S, Dobry CJ, Feinberg AP. (1995) Loss of imprinting in hepatoblastoma. Cancer Res. 55: 1836-1838.

79. Zhan S, Shapiro DN, Helman LJ. (1994) Activation of an imprinted allele of the insulin-like growth factor II gene implicated in rhabdomyosarcoma. J. Clin. Invest. 94: 445-448.

80. Stenman MJC, Rainier S, Dobry CJ, et al. (1994) Loss of imprinting of IGF2 is linked to reduced expression and abnormal methylation of $\mathrm{Hl9}$ in Wilms' tumor. Nat. Genet. 7: 433-439.

81. Feil R, Walter J, Allen ND, Reik W. (1994) Developmental control of allelic methylation in the imprinted mouse IGF2 and H19 genes. Development 120: 2933-2943.

82. Taniguchi T, Sullivan MJ, Ogawa O, et al. (1995) Epigenetic changes encompassing the IGF2/H19 locus associated with relaxation of IGF2 imprinting and silencing of H19 in Wilms tumor. Proc. Natl. Acad. Sci. U.S.A. 92: 2159-2163.

83. Cui H, Niemitz EL, Ravenel JD, et al. (2001) Loss of imprinting of insulin-like growth factor-II in Wilms' tumor commonly involves altered methylation but not mutations of CTCF or its binding site. Cancer Res. 61: 4947-4950.

84. Burns JL, Jackson DA, Hassan AB. (2001) A view through the clouds of imprinting. FASEB J. 15: 1694-1703.

85. Hark AT, Schoenherr CJ, Katz DJ, et al. (2000) CTCF mediates methylation-sensitive enhancer-blocking activity at the H19/Igf2 locus. Nature 405: 486-489.

86. Bell AC, Felsenfeld G. (2000) Methylation of a CTCFdependent boundary controls imprinted expression of the Igf2 gene. Nature 405: 482-485.

87. Chen CL, Ip SM, Cheng D, et al. (2000) Loss of imprinting of the IGF-II and H19 gene in epithelial ovarian cancer. Clin. Cancer Res. 6: 474-479.

88. Little M, van Heyningen V, Hastie N. (1991) Dads and disomy and disease. Nature 351: 609-610.

89. Little MH, Dunn R, Byrne JA, et al. (1992) Equivalent expression of paternally and maternally inherited WTl alleles in normal and fetal tissue and Wilms' tumours. Oncogene 7: 635-641.

90. Li X, Adam G, Cui H, et al. (1995) Expression, promoter usage and parental imprinting status of insulin-like growth factor II (IGF2) in human hepatoblastoma: uncoupling of IGF2 and H19 imprinting. Oncogene 11: 221-229.

91. Uyeno S, Acki Y, Nata M, et al. (1996) IGF2 but not H19 shows loss of imprinting in human glioma. Cancer Res. 56: 5356-5359.

92. Hatada I, Ohashi H, Fukushima Y, et al. (1996) An imprinted gene $\mathrm{p} 57^{\mathrm{KIP} 2}$ is mutated in Beckwith-Wiedemann syndrome. Nature 14: 171-173.

93. Bockmuhl U, Petersen I, Schwendel A, Dietel M. (1996) Genetic screening of head-neck carcinomas using comparative genomic hybridization. Laryngo-Rhino-Otologie 75: 408-414.

94. Bockmuhl U, Wolf G, Schwendel A, et al. (1998) Genomic alterations associated with malignancy in head and neck cancer. Head Neck Surg. 20: 145-151.

95. Newsham IF. (1998) The long and short arm of chromosome 11 in breast cancer. Am. J. Pathol. 153: 5-9.

96. Tran YK, Newsham IF. (1996) Hugh-density marker analysis of 11 p15.5 in non-small cell lung carcinomas reveals allelic deletion of one shared and one distinct region when compared to breast carcinomas. Cancer Res. 56: 2916-2921.

97. Besnard-Guerin C, Newsham I, Winqvist R, Cavenee WK. (1996) A common region of loss of heterozygosity in Wilms tumor and embryonal rhabdomyosarcoma distal to the D11S988 locus on chromosome 11p15.5. Hum. Genet. 97: 163-170.

98. Rainho CA, Kowalski LP, Rogatto SR. (2001) Loss of imprinting and loss of heterozygosity on 11 p15.5 in head and neck squamous cell carcinomas. Head Neck 23: 85 1-859.

99. Scrable H, Cavenee W, Ghavimi F, et al. (1989) A model for embryonal rhabdomyosarcoma tumorigenesis that involves genome imprinting. Proc. Natl. Acad. Sci. U.S.A. 86: 7480-7484.

100. Yun K. (1993) Clear cell sarcoma of the kidney expresses insulin like growth factor-II but not WTI transcripts. Am. J. Pathol. 142: 39-47. 
101. Buckbinder L, Talbot R, Velascomiguel S, et al. (1995) Induction of the growth inhibitor IGF-binding protein 3 by p53. Nature 377: 646-649.

102. Drummond IA, Madden SL, Rohwer-Nutter P, et al. (1992) Repression of the insulin-like growth factor II gene by the Wilms tumor suppressor WT1. Science 257: 674-678.

103. Pedone PV, Tirabosco R, Cavazzana AO, et al. (1994) Monoand bi-allelic expression of insulin-like growth factor II gene in human muscle tumors. Human Mol. Genet. 3: 1117-1121.

104. Nielsen FC, Orskov C, Haselbacher G, et al. (1994) Insulinlike growth factor II mRNA, peptides, and receptors in a thoracopulmonary malignant small round cell tumor. Cancer 73: 1312-1319.

105. Mohan S, Strong DD, Lempert UG, et al. (1992) Studies on regulation of insulin-like growth factor binding protein (IGFBP)-3 and IGFBP-4 production in human bone cells. Acta Endocrinologica 127: 555-564.

106. Reeve JG, Brinkman A, Hughes S, et al. (1992) Expression of insulin-like growth factor (IGF) and IGF-binding protein genes in human lung tumor cell lines. J. Natl. Cancer Inst. 84: 628-634.

107. Cohen P, Peehl DM, Stamey TA, et al. (1993) Elevated levels of insulin-like growth factor-binding protein-2 in the serum of prostate cancer patients. J. Clin. Endocrinol. Metab. 76: 1031-1035.

108. Lee PD, Suwanichkul A, DePaolis LA, et al. (1993) Insulinlike growth factor (IGF) suppression of IGFBP-1 production: evidence for mediation by the type I IGF receptor. Regul. Pept. 48: 199-206.

109. Ho MN, Delgado CH, Owens GA, Steller MA. (1997) Insulin-like growth factor-II participates in the biphasic effect of a gonadotropin-releasing hormone agonist on ovarian cancer cell growth. Fertil. Steril. 67: 870-876.

110. Manetta A, Gamboa-Vujicic G, Paredes P, et al. (1995) Inhibition of growth of human ovarian cancer in nude mice by luteinizing hormone-releasing hormone antagonist Cetrorelix (SB-75). Fertil. Steril. 63: 282-287.

111. Kleinman D, Roberts CT Jr, LeRoith D, et al. (1993) Regulation of endometrial cancer cell growth by insulin-like growth factors and luteinizing hormone-releasing hormone antagonist SB-75. Regul. Pept. 48: 91-98.

112. Hershkovitz E, Marbach M, Bosin E, et al. (1993) Luteinizing hormone-releasing hormone antagonists interfere with autocrine and paracrine growth stimulation of MCF-7 mammary cancer cells by insulin-like growth factors. J. Clin. Endocrinol. Metab. 77: 963-968.

113. Csernus EJ, Schally AV, Kiaris H, Armatis P (1999) Inhibition of growth, production of insulin-like growth factor-II (IGFII), and expression of IGF-II mRNA of human cancer cell lines by antagonistic analogs of growth hormone-releasing hormone in vitro. Proc. Natl. Acad. Sci. U.S.A. 96: 3098-3103.
114. McCaulay VM. (1992) Insulin-like growth factors and cancer. Br. J. Cancer 65: 311-320.

115. Pollak M, Richard M. (1990) Suramin blockade in insulinlike growth factor I stimulated proliferation of human osteosarcoma cells. J. Natl. Cancer Inst. 82: 1349-1352.

116. Lahm H, Amstad P, Wyniger J, et al. (1994) Blockade of the insulin-like growth-factor-I receptor inhibits growth of human colorectal cancer cells: evidence of a functional IGF-IImediated autocrine loop. Int. J. Cancer 58: 452-459.

117. Macaulay VM, Everard MJ, Teale JD, et al. (1990) Autocrine function for insulin-like growth factor I in human small cell lung cancer cell lines and fresh tumors. Cancer Res. 50: 2511-2517.

118. Arteaga CL. (1992) Interference of the IGF system as a strategy to inhibit breast cancer growth. Breast Cancer Res. Treat. 22: 101-106.

119. Trojan J, Blossey BK, Johnson TR, et al. (1992) Loss of tumorigenicity of rat glioblastoma directed by episome-based antisense cDNA transcription of insulin-like growth factor I. Proc. Natl. Acad. Sci. U.S.A. 89: 4874-4878.

120. Shapiro DN, Jones BG, Shapiro LH, et al. (1994) Antisensemediated reduction in insulin-like growth factor I receptor expression suppresses the malignant phenotype of a human alveolar rhabdomyosarcoma. J. Clin. Invest. 94: 1235-1242.

121. Lee CT, Wu S, Gabrilovich D, et al. (1996) Antitumor effects of an adenovirus expressing antisense insulin-like growth factor I receptor on human lung cancer cell lines. Cancer Res. 56: 3038-3041.

122. Zia F, Jacobs S, Kull F Jr, et al. (1996) Monoclonal antibody alpha IR-3 inhibits non-small cell lung cancer growth in vitro and in vivo. J. Cell. Biochem. 24(suppl): 269-275.

123. Goossens K, Esquenet M, Swinnen JV, et al. (1999) Androgens decrease and retinoids increase the expression of insulin-like growth factor-binding protein-3 in LNCaP prostatic adenocarcinoma cells. Mol. Cell. Endocrinology 155: 9-18.

124. Martin JL, Coverley JA, Pattison ST, Baxter RC. (1995) Insulin-like growth factor-binding protein-3 production by MCF-7 breast cancer cells: stimulation by retinoic acid and cyclic adenosine monophosphate and differential effects of estradiol. Endocrinology 136: 1219-1226.

125. Gucev ZS, Oh Y, Kelley KM, Rosenfeld RG. (1996) Insulinlike growth factor binding protein-3 mediates retinoids acid- and transforming growth factor $\beta 2$-induced growth inhibition in human breast cancer cells. Cancer Res. 56: $1545-1550$.

126. Hwa V, Oh Y, Rosenfeld RG. (1997) Insulin-like growth factor binding protein-3 and -5 are regulated by transforming growth factor- $\beta$ and retinoic acid in the human prostate adenocarcinoma cell line PC-3. Endocrine 6: 235-242.

127. Helle SI, Lonning PE. (1996) Insulin-like growth factors in breast cancer. Acta Oncol. 35(suppl 5): 19-22. 